\title{
Systematics and biogeography of the genus Phalloptychus Eigenmann, 1907 (Cyprinodontiformes: Poeciliidae: Poeciliinae)
}

\author{
Paulo H. F. Lucinda
}

\begin{abstract}
The genus Phalloptychus is revised. Phalloptychus iheringii is removed from the synonym of $P$. januarius. Three species are recognized: P. eigenmanni, P. januarius, and $P$. iheringii. Phalloptychus eigenmanni can be distinguished from its congeners by the number of pelvic-fin rays in females, the number of predorsal scales, and the predorsal distance in females. Phalloptychus iheringii and $P$. januarius can be distinguished by the number of epipleural ribs, number of gonopodial rays, and a significantly different number of vertical bars along body side in females. Lectotypes are designated for Girardinus iheringii and G. januarius. Redescriptions and known distribution ranges are provided for each species as well as an identification key. Derived features supportting the monophyly of the genus and infrageneric clades are presented and discussed. The biogeographic implications of the geographic distribution of Phalloptychus species are discussed.

O gênero Phalloptychus é revisado. Phalloptychus iheringii é retirado da sinonímia de P. januarius, e três espécies são reconhecidas: P. eigenmanni, P. januarius e P. iheringii. Phalloptychus eigenmanni pode ser distinguido dos seus congêneres pelo número de raios da nadadeira pélvica das fêmeas, pelo número de escamas pré-dorsais, e pela distância pré-dorsal nas fêmeas. Phalloptychus iheringii e $P$. januarius podem ser distinguidos pelo número de costelas epipleurais, pelo número de raios gonopodiais e por um número significantemente diferente de barras verticais ao longo dos flancos das fêmeas. Lectótipos são designados para Girardinus iheringii e G.januarius. Redescrições e amplitudes de distribuição conhecida são apresentadas para cada espécie bem como uma chave de identificação. São apresentados e discutidos caracteres derivados que corroboram a monofilia do gênero e dos clados infragenéricos. As implicações biogeográficas da distribuição geográfica das espécies de Phalloptychus são discutidas.
\end{abstract}

Key words: Neotropical, ichthyofauna, taxonomy, phylogeny, live-bearing, killifishes.

\section{Introduction}

The genus Phalloptychus Eigenmann, 1907 contains poeciliids endemic to South America occurring along the coastal drainages from Bahia to Rio Grande do Sul states of Brazil (Fig. 1). Males are typically smaller than females; the gonopodium is long and asymmetrical and bears spines along its length. Papers concerning Phalloptychus are extremely rare in systematic literature. These are mostly confined to original descriptions. Even from a biological standpoint Phalloptychus species are poorly studied.

The taxonomic history of Phalloptychus began with the first described species currently in the genus: Girardinus januarius Hensel, 1868, based on specimens from Rio de Janeiro. A second species, G. iheringii Boulenger, 1889, was described from Rio Grande do Sul on the basis of specimens collected by Hermann von Ihering. Garman (1895) synonymized G. iheringii and G. caudimaculatus Hensel, 1868 [=
Phalloceros caudimaculatus] with G. januarius, since the later had page priority over the second. Garman (1895) erected the genus Glaridodon on the basis of tooth and jaw morphology, with G. uninotatus Poey, 1854 as type species, and placed G. januarius in his new genus Glaridodon. The name Glaridodon is preoccupied in Therapsida, and Garman (1896) replaced it with Glaridichthys in the subsequent year. It is quite evident from Garman's (1895) figure of a Gl.januarius male (Plate VIII, fig. 15), showing a distal appendix on gonopodium, that he had only Phalloceros Eigenmann, 1907 specimens at hand. That is the reason why he considered both genera to be synonyms. Schneider \& Ribeiro's (1903) examination of the fish collection in the Museu Nacional do Rio de Janeiro, identified and recognized Gl. januarius and described G. zonatus based on specimens with uncertain locality.

Steindachner (1907) did not treat Glaridodon as a preoccupied name and recognized Glaridodon as a subgenus of Girardinus Poey, 1854 based on his examination of material

Laboratório de Ictiologia Sistemática, Universidade Federal do Tocantins, Campus de Porto Nacional, rua 3, quadra 17, s/n, Jardim dos Ipês, Caixa Postal 136, 77500-000 Porto Nacional, TO, Brazil. e-mail: lucinda@uft.edu.br. 


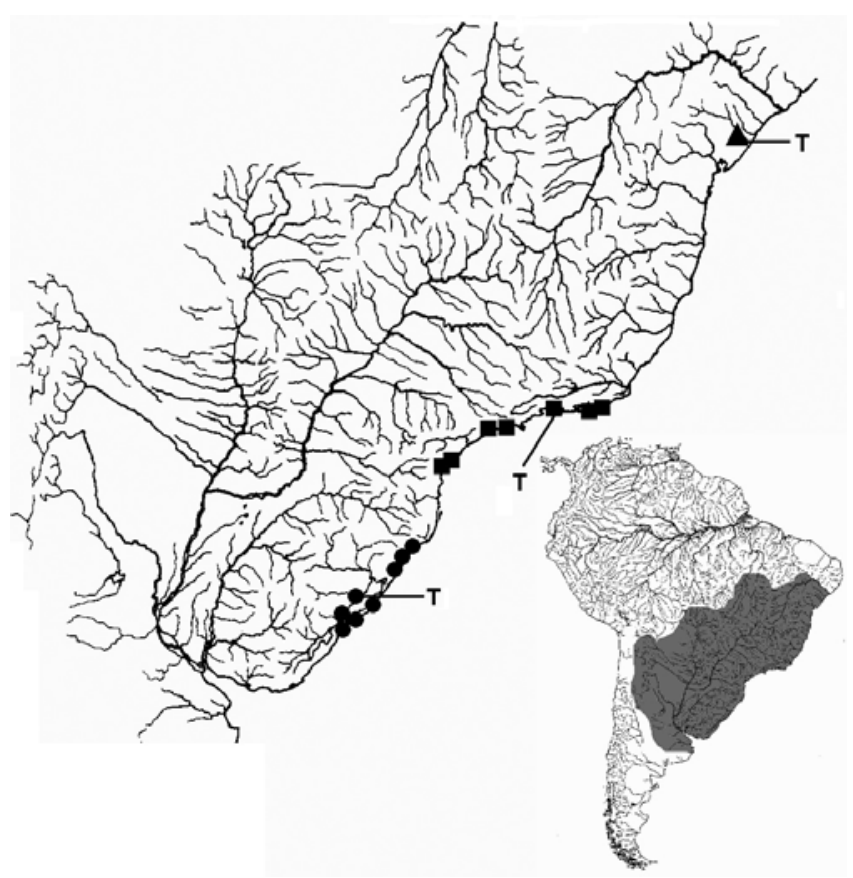

Fig. 1. Coastal drainages from Bahia to Rio Grande do Sul, and Uruguay showing distribution of Phalloptychus eigenmanni (triangle), P.januarius (squares), and $P$. iheringii (circles). Each symbol may represent more than one lot and/ or locality. $\mathrm{T}=$ type locality.

from Santa Catarina state. Eigenmann (1907) recognized Glaridichthys januarius as generically distinct from $G$. caudimaculatus on the basis of teeth and gonopodium structure. Therefore, Eigenmann (1907) created the genus Phalloptychus for Glaridichthys januarius, and erected the genus Phalloceros for G. caudimaculatus. Philippi (1908) considered $G$. caudimaculatus a junior synonym of Glaridichthys januarius, for he believed that Eigenmann created Phalloptychus and Phalloceros based respectively on juvenile and adult male specimens of Glaridichthys januarius. Moreover, judging from his figures he had solely examined specimens of $G$. caudimaculatus. Langer (1913) followed Philippi further confusing the situation. Regan (1913) in his revision of the Poeciliinae synonymized $G$. iheringii and $G$. zonatus with $P$.januarius. Henn (1916) following Eigenmann, recognized the distinctness of genera Phalloceros and Phalloptychus and described $P$. eigenmanni from specimens collected by Haseman in the rio Catu at Alagoinhas, Bahia. Henn also provided a redescription of $P$.januarius from specimens collected by Hermann von Ihering in the Rio Grande do Sul and cited Santa Catarina, Rio Grande do Sul, and Uruguay, as part of distribution range of the species. Rudolph von Ihering (1931) considered Phalloptychus composed by two subspecies: $P$. januarius januarius and $P$. januarius eigenmanni. More recently, Lucinda (2003) recognized three valid species in the genus: $P$. eigenmanni, $P$. iheringii, and $P$. januarius. Lucinda (2003) regarded Girardinus zonatus as Incertae Sedis in Poeciliinae, since syntypes are missing and the type locality is uncertain.
Lucinda \& Reis (2005: fig. 2a) presented (but not discussed) a phylogenetic hypothesis of relationships among Phalloptychus species. This hypothesis (Fig. 2) is part of a more inclusive phylogenetic study on the relationships among poeciliine genera. Thus, the phylogenetic position of the genus Phalloptychus in the subfamily Poeciliinae was discussed by Lucinda \& Reis (2005: fig. 1). Although the transformation series analysis was provided and intrageneric relationships of Phalloptychus were depicted by Lucinda \& Reis (2005), these authors did not present the diagnoses of intrageneric clades. These clade diagnoses are provided herein.

Thus, this paper has the following aims: (1) to diagnose the species of Phallotorynus and their geographic distribution; (2) present the diagnoses of the genus and its intrageneric clades and (3) and to propose a hypothesis of biogeographic relationships among those species.

\section{Material and Methods}

The entries under examined material for each species follow the sequence: country, state, museum acronym, catalogue number, total number of examined specimens in the lot (in parentheses; number of cleared and stained specimens is indicated by an asterisk and separated from total number by a bar), type status, collection locality, date, collector. Type localities are listed as in original descriptions. Museum acronyms are: BMNH - Natural History Museum, London; CM Carnegie Museum, Pittsburgh; FMNH - Field Museum of Natural History, Chicago; FURG - Fundação Universidade de Rio Grande, Rio Grande; MCP - Museu de Ciências e Tecnologia da Pontifícia Universidade Católica do Rio Grande do Sul, Porto Alegre; MHNCI - Museu de História Natural do Capão da Imbúia, Curitiba; MZUSP - Museu de Zoologia da Universidade de São Paulo, São Paulo; CAS-SU - Stanford University Collection at the California Academy of Sciences, San Francisco; UFPB - Universidade Federal da Paraíba, João Pessoa; UMMZ - University of Michigan Museum of Zoology, Ann Arbor; USNM - National Museum of Natural History, Smithsonian Institution, Washington, DC; and ZMB Museum für Naturkunde, Humboldt-Universität, Berlin.

Counts of scales, fin rays and vertebrae were taken according to Lucinda (2005). The three numbers in parentheses separated by bars following the vertebrae counts indicate respectively: number of vertebrae anterior to first dorsal pterygiophore, number of vertebrae between first and last dorsal pterygiophore, and number of vertebrae posterior to last dorsal pterygiophore. Other counts include (a) number of teeth on outer premaxillary row; (b) number of teeth on outer dentary row; (c) number of branchiostegal rays; (1) number of caudal-fin rays attached to hypural plate; (d) number of upper accessory cartilages; and (e) number of lower accessory cartilages. All counts, except scales, were performed in cleared and stained specimens. The minute and incompletely ossified ray attached to the last normal gonopodial ray has been considered in gonopodial ray-counts. Rudimentary and procurrent rays were included in pectoral and caudal fin 
counts, respectively. All counts were made on the left side of adult specimens whenever possible, except the number of teeth, which have been counted on both sides. In species descriptions, numbers in square brackets following the counts indicate number of specimens for each count.

Fourteen measurements were obtained as distances between 13 homologous landmarks on the lateral left surface of head and body, as described in Lucinda (2005). Tables of descriptive morphometrics were elaborated with "Datax, version 4.2" by Roberto Reis and Nelson Fontoura. Measurements, other than $\mathrm{SL}$, are expressed as percents of SL, except those that are subunits of the head, which are expressed as percents of HL.

Nonparametric statistical tests of null hypotheses of character similarity were performed using the software "Sigma Stat for Windows (Jandel Scientific), in order to evaluate meristic data that failed to pass tests for normality and equal variance. This methodology has been extensively described and commented by Weitzman \& Malabarba (1999).

Number and disposition of cephalic pores followed the nomenclature of Rosen \& Mendelson (1960), Gosline (1949), and Parenti (1981). Only adult individuals have been examined to avoid undesirable ontogenetic variation. Nomenclature of the gonopodium follows Rosen \& Gordon (1953) and Lucinda \& Reis (2005). Descriptions of gonopodium morphology are based on fully developed gonopodia of large adult males. Osteological nomenclature adopted followed Rosen \& Bailey (1963) and Parenti (1981). Clearing and staining followed the method of Taylor \& Van Dyke (1985). Cladistic procedures, character state assignments, transformation series and clade numbers follow the phylogenetic analysis performed by Lucinda \& Reis (2005). Character states illustrations are provided or referred to by Lucinda \& Reis (2005).

\section{Results}

Three Phalloptychus species are herein recognized: $P$. eigenmanni, $P$. januarius, and $P$. iheringii, whose descriptions are provided below. Autapomorphies and synapomorphies supporting the monophyly of the genus and the infrageneric clade are presented below. Two asterisks indicate uniquely derived and unreversed features.

\section{Phalloptychus Eigenmann \\ Clade 100, Lucinda \& Reis, 2005}

Phalloptychus Eigenmann, 1907: 426 [diagnosis in key], 430 [formal diagnosis], fig. 6. Gender masculine. Type species: Girardinus januarius Hensel, 1868. Type by original designation and monotypy.

Diagnosis. Phalloptychus species share the following uniquely derived and unreversed features: (1) extremely large dorsolateral process of basipterygium in adult males [36-2**] (Lucinda \& Reis, 2005: fig. 8c; 15); (2) first ray of left and right pelvic fins different from each other in adult males [40-1**] (Lucinda \& Reis, 2005: fig. 10); (3) first pelvic-fin ray of adult males very

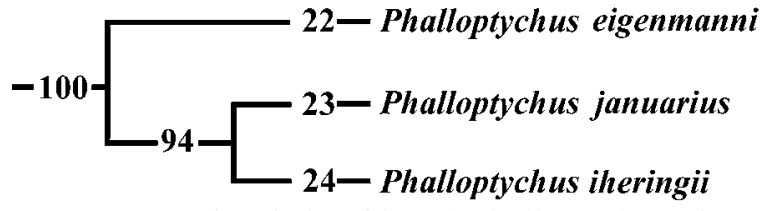

Fig. 2. Intrageneric relationships of Phalloptychus. The numbers on the branches refer to the character state transformations series listed by Lucinda \& Reis (2005).

wide, mainly right one [41-3**] (Lucinda \& Reis, 2005: fig. 10); (4) lateral projection near the bifurcation of second right pelvic-fin ray of adult males [43-1**] (Lucinda \& Reis, 2005: fig. 10a); (5) callosity at the distal portion of right pelvic fin of adult males [45-1**] (Lucinda \& Reis, 2005: fig. 12); (6) third gonapophysis angled zero-10 degrees relative to vertebral column [55-3**]; (7) pleural rib 9 of adult males well-developed, longer than remaining pleural ribs, curved forward and expanded at distal tip [58-1**]; (8) gonactinost complex axis little inclined backwards, forming an angle between $45^{\circ}$ and $90^{\circ}$ relative to body longitudinal axis [68-3**]; (9) short and dorsal protuberance close to base of R4p [117-1**] (Lucinda \& Reis, 2005: fig. 27); and (10) lower branch of R6 as long as upper branch [1291**]. Additionally, Phalloptychus species can be diagnosed by the following not uniquely derived and/or reversed features: (1) parietals absent [2-2] (Ghedotti, 2000: fig. 3); (2) epiotic process absent [3-3] (Ghedotti, 2000: fig. 3); (3) posterior section of posterior remnant of infraorbital system open forming a groove [7-1] (Rosen \& Mendelson, 1960: fig. 2A, B); (4) preorbital canal absent or open, forming a very shallow groove [9-2] (Rosen \& Mendelson, 1960: fig. 2C, D); (5) four pelvic-fin rays in males [33-2]; (6) ligastyle tripartite (three axis) [46-3] (Lucinda \& Reis, 2005: fig. 13c); (7) first gonapophysis approximately parallel to vertebral column [53-3]; (8) second gonapophysis approximately parallel to vertebral column [542]; (9) pleural ribs associated with haemal arches in males [601]; (10) pleural ribs associated with haemal arches in females [61-1]; (11) absence of a convex expansion on anterior border of second gonactinost [70-0]; (12) flanks with elongate vertical bars reaching dorsal and ventral profiles plus short bars on caudal peduncle [133-1] (Fig. 5; 7); and (13) orbital bones ab$\operatorname{sent}[143-0]$.

\section{Phalloptychus eigenmanni Henn} Figs. 3-4; Tables 1-2

Phalloptychus eigenmanni Henn, 1916: 121, Pl. 20, figs. 2-3. Type locality: Alagoinhas, rio Catu, Bahia.

Type material. Holotype: FMNH 55876 [ex CM 4665]. Paratypes: FMNH 55877 [ex-CM 4666] (4).

Diagnosis. Phalloptychus eigenmanni can be distinguished from its congeners by the number of pelvic-fin rays in females ( $6 v s$. 5, respectively), by the number of predorsal scales (13 vs. 10-12, respectively), and the longer predorsal distance in females (64.0-68.6 vs. 55.4-62.2\% SL, respectively). 
Description. Morphometric data in Tables 1-2. Range of SL: 21.8 to $22.8 \mathrm{~mm}$ (females), $15.7 \mathrm{~mm}$ (immature male). Body compressed; width in predorsal region uniform, and about half body depth. Postdorsal region compressed towards caudal peduncle. Dorsal profile of snout slightly concave. Dorsal profile of head slightly convex. Predorsal profile convex. Dorsal-fin base oblique. Postdorsal profile slightly convex. Pre-anal profile convex. Anal-fin base oblique; postanal profile almost straight. Dorsal fin located posterior to mid-body. Origin of dorsal fin in females approximately aligned with anal-fin end; in male (juvenile), origin of dorsal fin posterior to vertical passing through origin of anal fin. Pectoral fin with high insertion. Base of dorsalmost pectoral-fin ray closer to dorsal than to ventral profile. Pelvic fin small, surpassing origin of gonopodium in male; not reaching origin of anal fin in females. Origin of anal fin of male closer to snout tip than to caudal peduncle. Mouth superior, approximately aligned with base of dorsalmost pectoral-fin ray.

Dorsal-fin rays: 8 [1], 9 [1]. Pectoral-fin rays: 11 [1], 12 [1]. Pelvic-fin rays: 4 [1] (males), 6 [3] (females). Anal-fin rays (females): 10 [2]. Gonopodial rays: 8 [1]. Caudal-fin rays: 22 [1], 23 [1], 24 [1]. Predorsal scales: 13 [2], 14 [1]. Longitudinal series scales: 24 [3]. Scales around caudal peduncle: 16 [3]. Scales in transverse row: 7 [ $3+1$ counted on holotype photograph].

Preorbital ramus of cephalic sensory system represented by two grooved neuromasts. Preorbital canal absent. Anterior portion of supraorbital ramus (pores 1 and 2a) parallel to upper lip with two inconspicuous neuromasts on each side. Posterior portion of supraorbital ramus (pores 2b, 3, 4a) composed of two grooved neuromasts. Posterior remnants of infra-orbital ramus represented by two neuromasts (pores $4 \mathrm{~b}$, $5,6 a$ ) and by one canal open at both ends (pores $6 \mathrm{~b}$ and 7). Ventral infra-orbital line neuromasts not visible due to poor condition of material. Preopercular ramus represented by large canal along preopercular border and opened by two pores, and followed by two grooved neuromasts. Neuromasts on mandibular ramus not visible due to poor condition of material.

Color in alcohol. Description based on three female paratypes faintly colored. Eye light metallic-grey with white pupil. Ground color cream. Anus margin and genital papilla whitish yellow. Light yellow line along predorsal surface. Fins pale yellow. Belly and preventral area silvery yellow. Five to seven narrow brown bars along flanks.

Common names. Barrigudinho, guaru.

Ecology. Phalloptychus eigenmanni is included in the list of endangered fish species in Brazil (Rosa \& Menezes, 1996; MMA, 2004). Various collecting efforts have revealed unfruitful, even in the type locality. Phalloptychus eigenmanni is seriously endangered, probably extinct (Rosa \& Menezes, 1996).

Distribution. Phalloptychus eigenmanni is solely known from the type locality (Fig. 1).

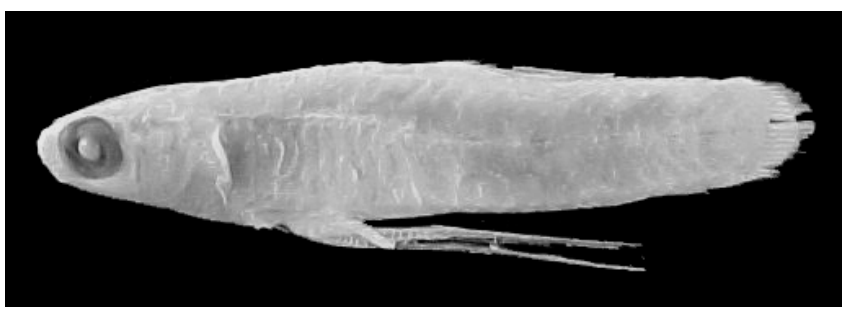

Fig. 3. Phalloptychus eigenmanni. FMNH 55877, rio Catu, Alagoinhas, Bahia, Brazil, paratype, immature male, $15.8 \mathrm{~mm}$ SL.

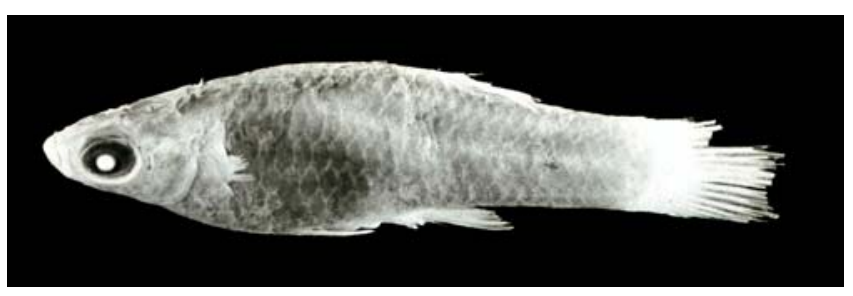

Fig. 4. Phalloptychus eigenmanni. FMNH 55876, rio Catu, Alagoinhas, Bahia, Brazil, holotype, female, $22.8 \mathrm{~mm}$ SL.

Remarks. Originally, Henn cited ten paratypes of P. eigenmanni. In 1956, Donn E. Rosen borrowed several lots from FMNH (loan \#Z-7445), including three paratypes of $P$. eigenmanni and possibly never returned them, although his loan was closed in 1970. Since then they have been considered missing in the FMNH. There is correspondence to FMNH (between Loren P. Woods and Donn E. Rosen) that suggests they might have remained at AMNH (with Woods' permission) and that Rosen might have turned them into skeleton preps (M. A. Rogers, pers. comm.). Although neither the original invoice nor the correspondence seem to indicate clearly that these are paratypes, they might be the specimens now housed in the American Museum of Natural History and catalogued as "Phalloptychus eigenmanni Henn, paratypes 3 spec. (1 missing), AMNH 22657 (FMNH 55877) from rio Catu, Alagoinhas" (B. Brown, pers. comm.). Collection data, number of specimens, number of male and female specimens of lots FMNH 55877 and AMNH 22657 suggest that they represent the original paratypic series of Henn. John D. Haseman collected both lots FMNH 55877 and AMNH 22657 in March 4 ${ }^{\text {th }}$, 1908. Following Haseman's itinerary during his expedition in South America (Eigenmann, 1911) it is evident that he has only collected in rio Catu, Alagoinhas at that date. Then, the aforementioned evidence leads to the conclusion that the three specimens of lot AMNH 22657 are actually the missing paratypes of P. eigenmanni from FMNH.

The sole mature male known from this species has been damaged during clearing and staining for the monograph of Rosen \& Bailey (1963). This specimen is a male that is now housed in the American Museum of Natural History as AMNH 22657 , from which only the head is still preserved. Since $P$. eigenmanni is probably extinct (Rosa \& Menezes, 1996; MMA, 2004), the only information about its gonopodium is that given in Rosen \& Bailey (1963: fig. 31E).

Examined material. Brazil. Bahia. FMNH 55877 (4). Paratypes. Alagoinhas, rio Catu, approx. 1208'S 38²6'W. 4 Mar 1908. J. D. Haseman. 


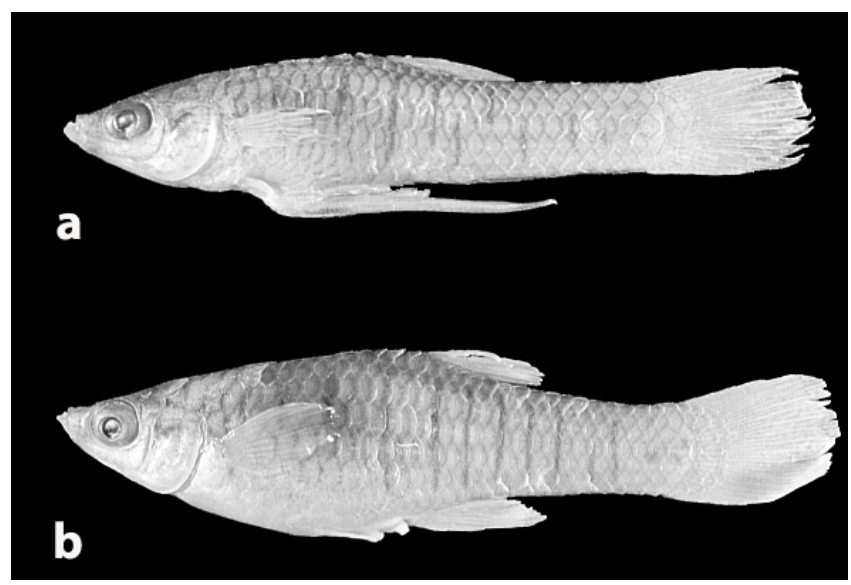

Fig. 5. Phalloptychus iheringii, MCP 11054, Tubarão, rio Tubarão and lateral channels near Campo Verde, Santa Catarina, Brazil. (a) male, $18.3 \mathrm{~mm} \mathrm{SL}$; (b) female, $25.7 \mathrm{~mm} \mathrm{SL}$.

\section{Phalloptychus iheringii + Phalloptychus januarius Clade 94, Lucinda \& Reis, 2005}

Diagnosis: Phalloptychus iheringii and $P$. januarius share the following not-uniquely derived feature: five pelvic-fin rays in females [44-1].

\section{Phalloptychus iheringii (Boulenger)}

Fig. 5; Tables 1-2

Girardinus iheringii Boulenger, 1889: 266. Type locality: Rio Grande do Sul. Restricted by Ihering (1893: 29) to "an der Mündung des Rio Camaquam" [= in the mouth of rio Camaquã].

Type material. Lectotype [present designation]: BMNH 1886.1.21.73. Paralectotypes: BMNH 1886.1.21.74-82 (9), CAS $62348(33)$.

Diagnosis. Phalloptychus iheringii can be autapomorphically diagnosed by the possession of eight anal-fin rays in males [86-3]. Furthermore, P. iheringii can be distinguished from $P$. eigenmanni by the number of pelvic-fin rays in females ( $5 v \mathrm{~s}$. 6 , respectively), by the number of predorsal scales (10-12 vs. 13 , respectively), and the shorther predorsal distance in females (55.6-61.3 vs. 64.0-68.6\% SL, respectively). P. iheringii is distinguished from P. januarius by the number of epipleural ribs (10-11 vs. 12-13 [one specimen had 11 in one side and 12 in the other], respectively), by the number of gonopodial rays ( $8 v s .9$, respectively), and by a significantly greater number of vertical bars along body sides of females (range $=8-18$, median $=12 v s$. range $=5-12$, median $=7$, respectively). Although some overlap occurs, Mann-Whitney rank sum tests (Fig. 6) indicate significant differences $(\mathrm{P}<0.001)$.

Description. Morphometric data in Tables 1-2. Range of SL: 22.4 to $34.1 \mathrm{~mm}$ (females), 14.4 to $20.0 \mathrm{~mm}$ (males). Body compressed; width in predorsal region uniform, and about half body depth. Postdorsal region compressed towards caudal peduncle. Dorsal profile of head slightly concave. Predorsal profile convex. Dorsal-fin base oblique. Postdorsal profile concave. Pre-anal profile convex. Anal-fin base oblique; postanal profile concave. Dorsal fin with semi-elliptical border, located posterior to mid-body. Origin of dorsal fin in females at vertical passing approximately through base of second anal-fin ray; in males, origin of dorsal fin posterior to vertical passing through origin of anal fin. Pectoral fin with high insertion. Base of dorsalmost pectoral-fin ray closer to dorsal than to ventral profile. Longest pectoral-fin ray of females reaching about fifth or sixth scale in longitudinal series. In adult males, origin of pectoral fin anterior to vertical passing through origin of pelvic fin. Pelvic fin small, surpassing origin of gonopodium in male; not reaching origin of anal fin in females. Origin of anal fin of male closer to snout tip than to caudal peduncle. Mouth superior, almost aligned with base of dorsalmost pectoral-fin ray.

Dorsal-fin rays: 9 [51]. Pectoral-fin rays: 10 [7], 11 [25], 12 [6]. Pelvic-fin rays: 4 [17] (males), 5 [27] (females). Anal-fin rays (females): 10 [26]. Gonopodial rays: 8 [3]. Caudal-fin rays: 23 [13], 24 [15], 25 [12]. Predorsal scales: 10 [12], 11 [28], 12 [8]. Longitudinal series scales: 27 [16], 28 [20]. Scales around caudal peduncle: 16 [43]. Scales in transverse row: 7 [3], 8 [38]. Epipleural ribs: 10 [2], 11 [7]. Pleural ribs: 13 [1], 14 [9]. Vertebrae: $32(12 / 5 / 15)[7],(11 / 5 / 16)[1],(11 / 6 / 15)$ [1]. Expanded neural processes: 4 [4], 5 [7]. Premaxillary teeth: 10 [4], 11 [1], 12 [2], 13 [1], 14 [1], 15 [1], 16 [1], 17 [1]. Dentary teeth: 8 [1], 9 [1], 10 [4], 11 [1], 13 [1], 14 [2], 16 [3], 18 [1]. Branchiostegal rays: 5 [8]. Caudal-fin rays attached to hypural plate: 9 [9]. Upper accessory cartilages: 1 [5], 2 [4]. Lower accessory cartilages: 1 [5], 2 [2].

Preorbital ramus of cephalic sensory system represented by two to five grooved neuromasts. Preorbital canal absent. Anterior portion of supraorbital ramus (pores 1 and 2a) parallel to upper lip with three inconspicuous neuromasts on each side. Posterior portion of supraorbital ramus (pores $2 \mathrm{~b}, 3,4 \mathrm{a}$ ) composed of two grooved neuromasts. Posterior remnants of infra-orbital ramus represented by three neuromasts (pores $4 \mathrm{~b}, 5,6 \mathrm{a}$ ) and by one short canal (pores $6 \mathrm{~b}$ and 7). Preopercular ramus represented by large canal (sometimes completely open, forming groove) along preopercular posterolateral border and by prolonged canal along preopercle ventral border opened by four pores. Opercular canal absent. Mandibular ramus composed of two or three superficial neuromasts (pores Z, $\mathrm{Ya}$, and $\mathrm{Yb}$ ) on anterior border of ventral surface of mandible and by one superficial neuromast near maxillary distal end (pore W).

Gonopodial complex composed of three functional gonapophyses and nine gonactinosts. Gonactinosts 2, 3, 4 fused. Gonactinost 4 with wing-like expansions. Ligastyle present. Gonopodium sinistrally asymmetrical. Eight gonopodial rays. R1 and R2 unbranched and short, with 8 segments. R3 with dorsal convexity located near base ranging from second to tenth or eleventh segments 2 to 10 or 11 . Tip of R3, R4a, and R4p ventrally bent and joint. Dorsal con- 
vexity located between segments 12 to 20 of R4p. Fourteen to fifteen spines on distal segments of R4p. Spines retrorse except two or three last spines directed forwards or upwards. R6, R7, and R8 branched. Five or six segments before bifurcation of R6. Anterior and posterior branches of R6 almost or fully ankylosed. Distal end of R6 modified in arrow-shaped expansion. R7 with six to eight segments anterior to bifurcation. Anterior and posterior branches of R7 moderately expanded and partially to completely ankylosed. Anterior branch of R7 greater than posterior. R8 with six or eight segments anterior to bifurcation. Anterior and posterior branches of R8 normal. Anterior branch of R8 greater than posterior. Six to eight segments on anterior branch of R8. R9 very minute not attached to pterygiophore.

Color in alcohol. Eye greenish grey, sometimes with shining yellow iridescence. Pupil greenish brown. Ground color cream, darker in upper half. Scales surface border and subjacent skin replete with many brown chromatophores, conferring reticulate pattern to body sides. Dark brown predorsal line. Brown chromatophores scattered through whole body, more concentrated in dorsal portion, mainly on head, snout, and ventral surface of mandible. Anus margin and urogenital area light yellow. Fins hyaline. Fin rays with two rows of brown chromatophores along each side, along extension of ray. Pale brown band on dorsal fin near its base (sometimes not easily seen). Eight to 18 narrow brown bars (median $=12$ ) along body sides of female specimens. Dark brown spot at base of R3.

Common names. Barrigudinho.

Distribution. Phalloptychus iheringii occurs in coastal drainages in Santa Catarina and Rio Grande do Sul states of Brazil (Fig. 1).

Remarks. Boulenger (1889) described Girardinus iheringii in honor of Hermann von Ihering who collected and sent him the specimens on which the description has been based (Ihering, 1893). This name has subsequently been used by Eigenmann \& Eigenmann (1891) referring to Rio Grande do Sul specimens. Boulenger originally cited the type locality as "Rio Grande do Sul", probably because it was the only collection information he had. Ihering (1893) states that type specimens have been collected "an der Mündung des Rio Camaquam" $[=$ in the mouth of rio Camaquã], thus restricting the type locality. In the same paper, however, Ihering claimed that G. iheringii should be regarded as a junior synonym of G. januarius, based on information provided in letter by Hingeldorf. Presumably, for this reason, subsequent authors have considered both names synonyms. However, the study of color pattern has revealed that the number of vertical bars along body sides of females is significantly greater in southern populations of Phalloptychus from Santa Catarina and Rio Grande do Sul (range $=8-18$, median $=12$ ) than for northern populations from Rio de Janeiro, São Paulo and Paraná (range $=5-12$, median $=7$ ). See Fig. 6 for a nonparametric statistical expression of differences and simi- larities among Phalloptychus populations. These differences along with differences in number of epipleural ribs and gonopodial rays give support to the resurrection of $P$. iheringii as a valid species.

Examined material. Lectotype [present designation], BMNH 1886.1.21.73, mouth of rio Camaquã, approx. $31^{\circ} 15^{\prime}$ 'S $51^{\circ} 47^{\prime} \mathrm{W}$. H. von Ihering. Paralectotypes, BMNH 1886.1.21.74-82 (9), same data as lectotype. CAS 62348, 20 of 33, H. von Ihering, 1893. Nontype specimens: Brazil. Santa Catarina: MCP 11016 (11), Laguna, channel connecting rio Tubarão to lagoa de Santa Marta, including pools and lateral channel, 8 Dec 1986. MCP 11054 (107/8*), Tubarão, rio Tubarão and lateral channels near Campo Verde. MCP 11515 (1), Tubarão, rio Tubarão and lateral channels near Campo Verde, 28 Nov 1986. MCP 26017 (11), Laguna, lagoa de Santa Marta, 27 Dec 1993. Rio Grande do Sul: FURG 79.0554 (6), São José do Norte, 6 Sep 1979. FURG 79.0652 (8), Rio Grande, Ponta da Marambaia, 16 Mar 1979. FURG 80.0238 (6), Rio Grande, Ilha dos Marinheiros, Porto Rei, 2 Apr 1980. FURG 80.0326 (6), Rio Grande, 11 Nov 1980. FURG 80.0327 (5), Rio Grande, Ilha do Leonildo, 24 Mar 1980. FURG 82.0339 (1), Rio Grande, 19 Jan 1982. FURG 82.0340 (2), São José do Norte, 18 Jan 1982. FURG 82.0341 (1), Rio Grande, 1 Mar 1982. MCP 25670 (2), Mostardas, swamp in road Talhamar to Parque Nacional da Lagoa do Peixe, 4 Feb 2000. MCP 26060 (2/1*), Rio Grande, Ilha dos Marinheiros, Porto Rei, 2 Apr 1980. MCP 26061 (3/1*), Rio Grande, 11 Nov 1980. MCP 26062 (2/1*), Rio Grande, Ilha dos Marinheiros, Ponta da Marambaia, 16 Mar 1979. UMMZ 65274 (2), 1893. USNM 235355 (5), Rio Grande, Ilha dos Marinheiros, Porto Rei, 22 Dec 1980. USNM 55640 (3), Rio Grande do Sul.

\section{Phalloptychus januarius (Hensel)}

Fig. 7; Tables 1-2

Girardinus januarius Hensel, 1868: 360. Type locality: "aus den Pfützen und Gräben um Rio de Janeiro" [= from the puddles and ditches around Rio de Janeiro].

Type material. Lectotype [present designation]: ZMB 7422. Paralectotypes: ZMB 33219 [originally ZMB 7422], ZMB 7424, and ZMB 31497.

Diagnosis. Phalloptychus januarius can be autapomorphically diagnosed by the possession of nine anal-fin rays in males [86-4]. Furthermore, Phalloptychus januarius can be distinguished from $P$. eigenmanni by the number of pelvicfin rays in females ( $5 v s .6$, respectively), by the number of predorsal scales (10-12 vs. 13, respectively), and the shorter predorsal distance in females (55.4-62.2 vs. 64.0-68.6 \% SL, respectively). Phalloptychus januarius is distinguished from $P$. iheringii by the number of epipleural ribs (12-13 [one specimen had 11 in one side and 12 in the other] vs. 10-11, respectively), by the number of gonopodial rays ( $9 v s .8$, respectively), and by a significantly lower number of vertical bars along body sides of females (range $=5-12$, median $=7, v s$. range $=8-18$, median $=12$, respectively). Although some overlap occurs, Mann-Whitney rank sum tests (Fig. 6) indicate significant differences $(\mathrm{P}<0.001)$. 


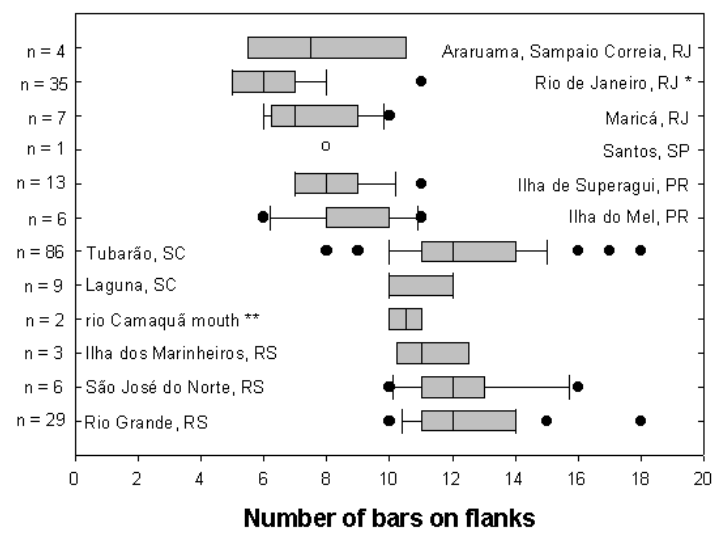

Fig. 6. Tukey box plot of number of bars along flanks in female specimens of Phalloptychus januarius and $P$. iheringii. Significant differences were found between $P$. januarius (Rio de Janeiro, São Paulo and Paraná) and $P$. iheringii populations (Santa Catarina and Rio Grande do Sul). * Type locality of $P$. januarius, ** type locality of $P$. iheringii.

Description. Morphometric data in Tables 1-2. Range of SL: 18.4 to $32.6 \mathrm{~mm}$ (females), 13.6 to $19.8 \mathrm{~mm}$ (males). Body compressed; width in predorsal region uniform, and about half body depth. Postdorsal region compressed towards caudal peduncle. Dorsal profile of head slightly concave. Predorsal profile convex. Dorsal-fin base oblique. Postdorsal profile concave. Pre-anal profile convex. Anal-fin base oblique; postanal profile slightly concave. Dorsal fin with semi-elliptical border, located posterior to mid-body. Origin of dorsal fin in females at vertical passing approximately through base of second anal-fin ray; in males, origin of dorsal fin posterior to vertical passing through origin of anal fin. Pectoral fin with high insertion. Base of dorsalmost pectoral-fin ray closer to dorsal than to ventral profile. Longest pectoral-fin ray of females reaching about fifth or sixth scale in longitudinal series. In adult males, origin of pectoral fin aligned with origin of pelvic fin. Pelvic fin small, surpassing origin of gonopodium in male; not reaching origin of anal fin in females. Origin of anal fin of male closer to snout tip than to caudal peduncle. Mouth superior, almost aligned with base of dorsalmost pectoral-fin ray.

Dorsal-fin rays: 9[52], 10[1]. Pectoral-fin rays: 10[10], 11[28], 12[9]. Pelvic-fin rays: 4[32] (males), 5[27] (females). Anal-fin rays (females): 10[25]. Gonopodial rays: 9[2]. Caudal-fin rays: 23[3], 24[19], 25[26], 26[1]. Predorsal scales: 11[14], 12[36]. Longitudinal series scales: 26[3], 27[27], 28[21], 29[4]. Scales around caudal peduncle: $16[60]$. Scales in transverse row: 8[38]. Epipleural ribs: 12 [9], 13 [2], (plus one specimen with 11 in one side and 12 in other). Pleural ribs: 13[2], 14[7]. Vertebrae: 31[6]: (11/5/15)[1],(12/4/15)[1],(12/5/14)[4]; 32[4]: (11/5/16)[1],(12/4/16)[1],(12/5/15)[2];33(12/6/15)[1]. Expanded neural processes: 4[6], 5[5]. Premaxillary teeth: 7[1], 8[1], 9[1], $10[3], 11[11], 12[2], 14[1], 15[1]$. Dentary teeth: 8[4], 9[1],10[2], 11[5], 12[6], 13[4]. Branchiostegal rays: 5[10], 6[1]. Caudal-fin rays attached to hypural plate: $9[11]$. Upper accessory cartilages: 2[3]. Lower accessory cartilages: 2[3].

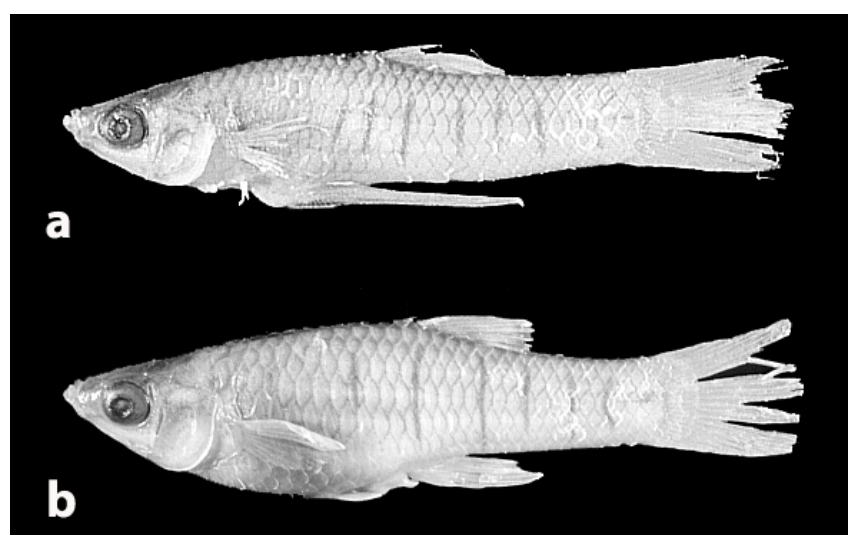

Fig. 7. Phalloptychus januarius. UMMZ 231550, Farol de São Tomé, Rio de Janeiro, Brazil. (a) male, $16.1 \mathrm{~mm} \mathrm{SL;} \mathrm{(b)}$ female, $21.9 \mathrm{~mm}$ SL.

Preorbital ramus of cephalic sensory system represented by one to three grooved neuromasts. Preorbital canal absent. Anterior portion of supraorbital ramus (pores 1 and 2a) parallel to upper lip with three inconspicuous neuromasts on each side. Posterior portion of supraorbital ramus (pores $2 b, 3,4 a$ ) composed of two or three grooved neuromasts. Posterior remnants of infra-orbital ramus represented by three neuromasts (pores $4 \mathrm{~b}, 5,6 \mathrm{a}$ ) and by one canal opened in both ends (pores $6 \mathrm{~b}$ and 7). About 15 inconspicuous neuromasts on ventral infra-orbital line. Preopercular ramus represented by large canal (sometimes completely open, forming groove) along preopercular posterolateral border and by prolonged canal along preopercle ventral border opened by four pores. Opercular canal absent. Mandibular ramus composed of two or three superficial neuromasts (pores $\mathrm{Z}$, Ya, and $\mathrm{Yb}$ ) on anterior border of ventral surface of mandible and by one superficial neuromast near maxillary distal end (pore W).

Gonopodial complex composed of three functional gonapophyses and nine gonactinosts. Gonactinosts 2, 3, 4 fused. Gonactinost 4 with wing-like expansions. Ligastyle present. Gonopodium sinistrally asymmetrical. Eight gonopodial rays. R1 and R2 unbranched and short, with 8 segments. R3 with dorsal convexity located near base ranging from second to tenth or eleventh segments. Tip of R3, R4a, and R4p ventrally bent and joint. Dorsal convexity located between segments 14 to 21 (rarely 12 to 18 ) of R4p. Twelve to 17 spines on distal segments of R4p. Spines retrorse except two or three last spines, directed forwards or upwards. R6, R7, R8 branched. Five to 8 segments before bifurcation of ray 6 . Anterior and posterior branches of R6 almost or fully ankylosed. Distal end of R6 modified in arrow-shaped expansion. R7 with six or seven segments anterior to bifurcation. Anterior and posterior branches of R7 moderately expanded and partially to completely ankylosed. Anterior branch of R7 greater than posterior. R8 with seven or eight segments anterior to bifurcation. Anterior and posterior branches of R8 normal. Anterior branch of R8 greater than posterior. Four to six segments on anterior branch of R8. Four segments on posterior branch of R8. R9 minute not attached to pterygiophore. 
Table 1. Descriptive morphometrics of males of Phalloptychus species. Measurements 1-10 are percents of standard length and measurements 11-13 are percents of head length.

\begin{tabular}{|c|c|c|c|c|c|}
\hline \multirow[t]{2}{*}{ Character } & \multirow[t]{2}{*}{$\begin{array}{l}\text { P. eigenmanni } \\
\mathrm{n}=1\end{array}$} & \multicolumn{2}{|c|}{$\begin{array}{c}\text { P. iheringii } \\
\mathrm{n}=19\end{array}$} & \multicolumn{2}{|c|}{$\begin{array}{c}\text { P. januarius } \\
\mathrm{n}=25\end{array}$} \\
\hline & & Range & Mean & Range & Mean \\
\hline Standard length (mm) & 15.7 & $14.4-20.0$ & 18.5 & $13.6-19.8$ & 17.3 \\
\hline 1. Head length & 22.0 & $21.0-23.9$ & 22.5 & $20.7-26.2$ & 23.2 \\
\hline 2. Snout-occipital distance & 16.5 & $17.1-20.4$ & 18.8 & $16.8-21.9$ & 19.3 \\
\hline 3. Predorsal distance & 9.0 & $49.8-55.0$ & 52.3 & $51.6-56.0$ & 53.4 \\
\hline 4. Dorsal-fin base length & 7.0 & $9.7-14.1$ & 10.9 & $8.4-14.2$ & 11.1 \\
\hline 5. Anal-fin base length & 11.1 & $8.5-12.2$ & 9.9 & $6.6-13.4$ & 10.0 \\
\hline 6. Body depth & 32.9 & $31.1-34.6$ & 32.5 & $30.8-36.3$ & 33.0 \\
\hline 7. Pre-pelvic length & 30.2 & $27.6-30.7$ & 29.1 & $28.7-33.5$ & 30.9 \\
\hline 8. Pre-anal length & 35.6 & $31.2-37.1$ & 33.7 & $31.7-37.9$ & 34.5 \\
\hline 9. Post-anal length & 56.5 & $58.0-63.6$ & 61.3 & $57.5-62.6$ & 60.3 \\
\hline 10. Caudal peduncle depth & 16.5 & $14.9-16.6$ & 15.8 & $13.9-18.0$ & 16.2 \\
\hline 11. Snout length & 19.6 & $16.6-25.1$ & 20.9 & $20.2-25.0$ & 22.4 \\
\hline 12. Orbital diameter & 43.5 & $35.4-43.1$ & 38.1 & $33.7-42.3$ & 37.3 \\
\hline 13. Postorbital length & 42.4 & $40.6-47.6$ & 44.0 & $37.7-50.1$ & 43.4 \\
\hline
\end{tabular}

Color in alcohol. Eye greenish grey. Pupil cream. Ground color cream, darker in upper half. Scales surface border and subjacent skin replete with many brown chromatophores, conferring reticulate pattern to body sides. Dark brown predorsal line. Brown chromatophores scattered through whole body, more concentrated in dorsal portion, mainly on head, snout, and ventral surface of mandible. Anus margin and urogenital area light yellow. Fins hyaline. Fin rays with two rows of brown chromatophores along each side, along extension of ray. Pale brown band on dorsal fin near its base (sometimes not easily seen). Five to 12 narrow brown bars (median $=7$ ) along body sides of female specimens. Dark brown spot at base of R3.

Common names. Barrigudinho, guaru.

Distribution. Phalloptychus januarius is known from coastal drainages in Rio de Janeiro, São Paulo and Paraná States of Brazil (Fig. 1).

Remarks. Besides the types examined, the type series includes the lots ZMB 7423 (4) and CAS-SU 1132 (1). It is not absolutely sure, whether the lot ZMB 31497 belongs to the type series, since this number is based secondarily on an old label from the anatomical collection: "No. 25204, R. Janeir [sic]" - the remainder of the label is illegible. This is the collection of the former "Institute of Anatomy of the HumboldtUniversity" in the 19th century. And this belonged to the Medical Faculty. This is due to the fact that human-anatomists were traditionally doing much research work on comparative anatomy of vertebrates. Thus, collected material was often divided between Zoological (Philosophical) Faculty with the Zoological Collection and the Medical Faculty. Only from approximately 1890 onwards the collections were reunited. But, apparently also R. Virchow, the famous pathologist working at the Charity Hospital at Humboldt-University took over some of the original anatomical collection for study (Paepke \& Seegers 1986; P. Bartsch in litt., 2000). As there is no apparent evidence that Hensel has not examined specimens from lot ZMB 31497, it is advisable to label the lot paralectotypes.
If future evidence demonstrates that these specimens are not syntypes, they will lose their paralectotype status.

Examined material. Brazil. Lectotype [present designation], ZMB

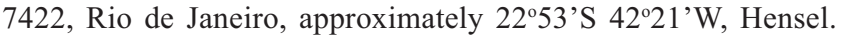
Paralectotypes, ZMB 33219 (1), same data as lectotype. ZMB 7424 (1), Rio de Janeiro, R. Hensel. ZMB 31497 (20), Rio de Janeir... [Sic]. Non-type specimens. Rio de Janeiro: MCP 8493 (65/4*), Rio de Janeiro, lagoa de Jacarepaguá, Dec 1979. MCP 9544 (10), Rio de Janeiro, lagoa de Jacarepaguá, Oct 1979. MZUSP 38370 (2), Araruama, Iguaba Grande, 1984. UFPB 2160 (9 of 37), Maricá, lagoa da Barra, 13 Jan 1988. UMMZ 231550 (10), Farol de São Tomé, 3 Nov 1989. USNM 331914 (4), rio Jundiá, tributary to lago de Saquarema, along road Amaral Peixoto, between Sampaio Correia and Bacaxa, 11 Nov 1982. São Paulo: MZUSP 50018 (1), Guarujá, Baía Branca, lagoon near sea. USNM 132422 (1), Santos, 13 Sep 1925. Paraná: MNHCI 6174 (15/4*), Guaraqueçaba, Ilha de Superagui, 28 Aug 1991. MNHCI 6183 (27/4*), Paranaguá, Ilha do Mel, Praia de Brasília, 16 Jul 1991.

\section{Key to the species of Phalloptychus.}

1. Females with six pelvic-fin rays; 13 predorsal scales; predorsal distance 64.0-68.6\% SL (rio Catu, Bahia).

Phalloptychus eigenmanni

1 '. Females with five pelvic-fin rays; $10-12$ predorsal scales; predorsal distance 55.4-62.2\% SL ................................... 2

2. Five to $12($ median $=7)$ vertical bars along body side in females; 12 or 13 epipleural ribs in adult specimens; 9 gonopodial rays; ninth minute, incompletely ossified gonopodial ray present (Coastal drainages from Rio de Janeiro to Paraná) .................... Phalloptychus januarius

2 '. Eight to 18 (median $=12)$ vertical bars along body sides in females; 9 to 11 epipleural ribs on adult specimens; 8 gonopodial rays (Coastal drainages of Santa Catarina and Rio Grande do Sul) Phalloptychus iheringii

\section{Discussion}

The genus Phalloptychus is a well-diagnosed, monophyletic group (Lucinda \& Reis, 2005). The genus is traditionally allocated in the tribe Cnesterodontini Hubbs. This tribe, as 
Table 2. Descriptive morphometrics of females of Phalloptychus species. Measurements 1-10 are percents of standard length and measurements 11-13 are percents of head length.

\begin{tabular}{|c|c|c|c|c|c|c|}
\hline \multirow[t]{2}{*}{ Character } & \multicolumn{2}{|c|}{$\begin{array}{l}\text { P. eigenmanni } \\
\mathrm{n}=2\end{array}$} & \multicolumn{2}{|c|}{$\begin{array}{c}P . \text { iheringii } \\
\mathrm{n}=48\end{array}$} & \multicolumn{2}{|c|}{$\begin{array}{c}P . \text { januarius } \\
\mathrm{n}=34\end{array}$} \\
\hline & Range & Mean & Range & Mean & Range & Mean \\
\hline Standard length (mm) & $21.8-22.8$ & 22.3 & $22.4-34.1$ & 26.4 & $18.4-32.6$ & 23.7 \\
\hline 1. Head length & $23.2-23.8$ & 23.5 & $20.9-26.2$ & 23.1 & $21.7-26.6$ & 24.1 \\
\hline Snout-occipital distance & $18.6-21.4$ & 20.0 & $16.4-21.7$ & 18.6 & $17.9-21.8$ & 20.0 \\
\hline Predorsal distance & $64.0-68.6$ & 66.3 & $55.6-61.3$ & 58.4 & $55.4-62.2$ & 58.4 \\
\hline Dorsal-fin base length & $7.3-8.8$ & 8.1 & $8.8-13.8$ & 11.2 & $8.1-13.5$ & 10.8 \\
\hline Anal-fin base length & $7.6-8.9$ & 8.2 & $8.6-11.9$ & 10.2 & $7.7-12.2$ & 10.1 \\
\hline Body depth & $26.9-29.8$ & 28.4 & $27.1-33.3$ & 29.6 & $25.4-32.2$ & 27.7 \\
\hline Pre-pelvic length & $43.7-45.9$ & 44.8 & $43.5-49.6$ & 46.6 & $42.3-49.8$ & 45.6 \\
\hline Pre-anal length & $56.5-58.6$ & 57.6 & $55.8-62.8$ & 59.0 & $54.4-63.0$ & 57.8 \\
\hline Post-anal length & $36.4-38.9$ & 37.6 & $32.9-37.8$ & 35.8 & $33.0-39.1$ & 36.2 \\
\hline 10. Caudal peduncle depth & $15.7-16.4$ & 16.1 & $13.5-16.8$ & 15.1 & $13.3-16.8$ & 15.2 \\
\hline 11. Snout length & $15.8-21.4$ & 18.6 & $16.5-27.0$ & 21.2 & $19.7-27.7$ & 23.4 \\
\hline 12. Orbital diameter & $40.5-40.6$ & 40.6 & $31.9-41.0$ & 36.7 & $29.0-39.4$ & 34.7 \\
\hline 13. Postorbital length & $41.4-45.3$ & 43.3 & $38.8-50.7$ & 46.7 & $38.6-49.6$ & 45.3 \\
\hline
\end{tabular}

originally defined by Hubbs (1924), was composed of genera Phalloceros, Cnesterodon Garman, 1895, Phallotorynus Henn, 1916, and Diphyacantha Henn, 1916. Hubbs (1926) added Darienichthys Hubbs, 1926 to the Cnesterodontini, which was excluded together with Diphyacantha by Rosen \& Bailey (1963). These authors also included Phalloptychus in the tribe. Later, Ghedotti (2000) included Tomeurus Eigenmann, 1907. Lucinda $\&$ Reis (2005) put forward a proposal of a new classification for the subfamily Poeciliinae in the basis of a phylogenetic analysis of 144 primarily osteological characters, in which Cnesterodontini is redefined and restricted to the genera Cnesterodon, Phalloceros, and Phallotorynus. According to Lucinda \& Reis (2005) the tribe Cnesterodontini sensu Rosen \& Bailey is paraphyletic, given that Phalloptychus is more closely related to the genera Poeciliopsis Regan, 1913; Xenophallus Hubbs, 1924; Phallichthys Hubbs, 1924; and Girardinus than to Cnesterodon, Phalloceros and Phallotorynus. The genera Poeciliopsis, Xenophallus, Phallichthys, and Girardinus together with Phalloptychus constitute a monophyletic assemblage, namely the tribe Girardinini Hubbs, 1924 sensu Lucinda \& Reis (2005).

At present, the distribution pattern of Phalloptychus is indecipherable on the basis of current evidence; as a result few assumptions can be attempted in order to enlighten such a pattern. The three species inhabit lowland drainages along the Brazilian coast. Phalloptychus januarius and $P$. iheringii are sister species isolated from each other by the Serra Geral formation, which prevents freshwater exchange during inundation events. Similar patterns have been identified for characiform and cyprinodontiform groups by different authors, e.g. monophyletic group of Spintherobolus Eigenmann, 1911; some species of Hyphessobrycon Durbin, 1908 (Weitzman \& Malabarba, 1999), Hollandichthys Eigenmann, 1909 (V. Bertaco, pers. comm.), Glandulocauda Eigenmann, 1911; Mimagoniates Regan, 1907; Rachoviscus Myers, 1926; Deuterodon Eigenmann, 1907 (Weitzman et al., 1988), Jenynsia Günther, 1866 (Ghedotti, 1998). Weitzman \& Malabarba (1999) suggested that sea level fluctuations in the Pleistocene are related to the isolation of ancient widespread species and to speciation events concerning this biota.
A striking feature of Phalloptychus distribution is the large gap between the $P$. eigenmanni and the remaining species. There is no apparent geological evidence that could explain this gap. Past sea level fluctuations may also be involved in the isolating of $P$. eigenmanni, but they are not sufficient to explain the gap. Extinction of intermediate ancient populations may also have occurred, which leads to the assumption that Phalloptychus may have been more widespread in ancient times than nowadays.

\section{Acknowlegments}

For loan of specimens, I am grateful to Anne-Marie Hine and James Maclaine (BMNH), Barry Chernoff and Mary Anne Rogers (FMNH), Douglas Nelson and William Fink (UMMZ), Osvaldo Oyakawa (MZUSP), José Pezzi da Silva and Roberto Reis (MCP), Marlise Bemvenuti (FURG), Peter Bartsch (ZMB), Ricardo Rosa (UFPB), Richard Vari and Susan Jewett (USNM), and Vinícius Abilhôa (MHNCI). I am also grateful to Barbara Brown (AMNH) and Mary Anne Rogers for providing information concerning Rosen's $P$. eigenmanni loan. I am greatly indebted to Ricardo Rosa, who kindly also provided information about old loans. I thank Peter Bartsch for providing information about ZMB collection. The manuscript benefited from reviews by Carlos Lucena, Luiz Malabarba, Márcio Martins, Roberto Reis (all from MCP), Ricardo Rosa (UFPB), and two anonymous reviewers. Ricardo Rosa and Edson Pereira (MCP) photographed the specimens. This study was developed during a doctoral program at the Pontifícia Universidade Católica do Rio Grande do Sul (PUCRS) and was supported by the Universidade do Tocantins (UNITINS), the Universidade Federal do Tocantins (UFT), and Coordenação de Aperfeiçoamento de Pessoal de Nível Superior (CAPES PICDT doctoral fellowship).

\section{Literature Cited}

Boulenger, G. A. 1889. Descriptions of a new snake and two new fishes obtained by Dr. H. von Ihering in Brazil. An- 
nals and Magazine of Natural History, 4(22):265-267.

Eigenmann, C. H. 1907. The poeciliid fishes of Rio Grande do Sul and the La Plata Basin. Proceedings of United States National Museum, 32(1532):425-433.

Eigenmann, C. H. 1911. The localities at which Mr. Haseman made collections. Annals of the Carnegie Museum, 7:299-314.

Eigenmann, C. H. \& R. S. Eigenmann. 1891. A catalogue of freshwater fishes of South America. Proceedings of United States National Museum, 14(842):1-81.

Garman, S. 1895. The Cyprinodonts. Memoirs of the Museum of Comparative Zoology, 19:1-179.

Garman, S. 1896. Cross fertilization and sexual rights and lefts among vertebrates. American Naturalist, 30:232.

Ghedotti, M. J. 1998. Phylogeny and classification of the Anablepidae (Teleostei: Cyprinodontiformes). Pp. 561-582. In: Malabarba, L. R., R. E. Reis, R. P. Vari, Z. M. Lucena, \& C. A. S. Lucena (Eds.). Phylogeny and Classification of Neotropical Fishes. Porto Alegre, Edipucrs, 603p.

Ghedotti, M. J. 2000. Phylogenetic analysis and taxonomy of the poeciloid fishes (Teleostei, Cyprinodontiformes). Zoological Journal of the Linnean Society, 130:1-53.

Gosline, W. A. 1949. The sensory canals of the head in some Cyprinodont fishes, with particular reference to the genus Fundulus. Occasional Papers of the Natural History Museum, University of Kansas, 519:1-17.

Henn, A. W. 1916. On various South American Poeciliid fishes. Annals Carnegie Museum, 10(1/2):93-142.

Hubbs, C. L. 1924. Studies of the fishes of the order Cyprinodontes. Miscellaneous Publications of the $\mathrm{Mu}-$ seum of Zoology, University of Michigan, 13:1-31, pls. 1-4.

Hubbs, C. L. 1926. Studies of the fishes of the order Cyprinodontes. VI. Miscellaneous Publications of the $\mathrm{Mu}-$ seum of Zoology, University of Michigan, 16:1-86, pls. 1-4.

Ihering, H. von. 1893. Die Susswasser-fische von Rio Grande do Sul. Kozeritz Deutscher Volkkalander für Brasilien, Porto Alegre, Gundlach, p. 95-128.

Ihering, R. von. 1931. Cyprinodontes Brasileiros (Peixes Guarus). Systemática e Informações Biológicas. I. Archivos do Instituto Biológico de São Paulo, 4:243-280.

Langer, W. F. 1913. Beiträge zur Morphologie der viviparen Cyprinodontiden. Morphologisches Jahrbuch, 47(1-2):193-307.

Lucinda, P. H. F. 2003. Family Poeciliidae. Pp. 555-581. In: Reis, R.E., S.O. Kullander \& C. Ferraris Jr. (Eds.), Check List of the Freshwater Fishes of South and Central America., Porto Alegre, Edipucrs, 729p.

Lucinda, P. H. F. 2005. Systematics of the genus Cnesterodon Garman, 1895 (Cyprinodontiformes: Poeciliidae: Poeciliinae). Neotropical Ichthyology, 3(2):259-270.

Lucinda, P. H. F. \& R. E. Reis. 2005. Systematics of the subfamily Poeciliinae Bonaparte (Cyprinodontiformes, Poeciliidae). Neotropical Ichthyology, 3(1):1-60.

Ministério do Meio Ambiente (MMA). 2004. Lista Nacional das Espécies de Invertebrados Aquáticos e Peixes Ameaçadas de Extinção. Instrução Normativa n ${ }^{\circ}$, de 21 de maio de 2004. Ministério do Meio Ambiente. Brasília. Diário Oficial da União n 102, de 28 de maio de 2003, Seção 1, páginas 136-142.
Paepke, H. -J. \& L. Seegers. 1986. Kritischer Katalog der Typen und Typoide der Fischsammlung des Zoologischen Museums Berlin. Mitteilungen aus dem Museum für Naturkunde in Berlin, Zoologische Reihe 62(1):135-186.

Parenti, L. R. 1981. A phylogenetic and biogeographical analysis of Cyprinodontiform fishes (Teleostei, Atherinomorpha). Bulletin of the American Museum of Natural History, 168(4):341-557.

Phillipi, E. 1908. Fortpflanzungsgeschichte der viviparen Teleosteer. Glaridichthys januarius und G. decemmaculatus in ihrem Einfluss auf Lebensweise, makroskopische und mikroskopische Anatomie. Zoologisches Jahrbuch, 27:1-94.

Regan, C. T. 1913. A revision of the Cyprinodont fishes of the subfamily Poeciliinae. Proceedings of the Zoological Society, London, 5:977-1019.

Rosa, R. S. \& N. A. Menezes. 1996. Relação preliminar das espécies de peixes (Pisces, Elasmobranchii, Actinopterygii) ameaçadas no Brasil. Revista Brasileira de Zoologia, 13(3):647-667.

Rosen, D. E. \& R. M. Bailey. 1963. The poeciliid fishes (Cyprinodontiformes) their structure, zoogeography and systematics. Bulletin of the American Museum of Natural History, 126(1):1-176.

Rosen, D. E. \& M. Gordon. 1953. Functional anatomy and evolution of male genitalia in Poeciliid fishes. Zoologica, 38(1):1-47.

Rosen, D. E. \& J. R. Mendelson. 1960. The sensory canals of head in Poeciliid fishes (Cyprinodontiformes), with reference to dentitional types. Copeia, 1960:203-210.

Schneider, C. \& A. M. Ribeiro. 1903. A colecção de peixes do Museu Nacional do Rio de Janeiro. Archivos do Museum Nacional, 12:67-109.

Steindachner, F. 1907. Über einige Fischarten aus dem Flusse Cubatão in Staate Santa Catharina, bei Therezopolis (Brasilien). Sitzungsberichte der Akademie der Wissenschaften, Wien, 116(1):475-92, 2 pls.

Taylor, W. R. \& G. C. Van Dyke. 1985. Revised procedures for staining and clearing small fishes and other vertebrates for bone and cartilage study. Cybium, 9:107-119.

Weitzman, S. H. \& L. R. Malabarba. 1999. Systematics of Spintherobolus (Teleostei: Characidae: Cheirodontinae) from eastern Brazil. Ichthyological Explorations of Freshwaters, 10(1):1-43.

Weitzman, S. H., N. A. Menezes \& M. J. Weitzman. 1988. Phylogenetic biogeography of the Glandulocaudini (Teleostei: Characiformes, Characidae) with comments on the distributions of other freshwater fishes in eastern and southeastern Brazil. Pp. 379-427. In: Heyer, W.R. \& P.E. Vanzolini (Eds.). Proceedings of a 1987 Workshop. Rio de Janeiro, Academia Brasileira de Ciência.

Received November 2004 Accepted March 2005 